\title{
Transport system modelling based on analogies between road networks and electrical circuits
}

\author{
A. V. Tolmachev ${ }^{1}$, E. V. Sinitsyn ${ }^{2} \bowtie$, D. A. Brusyanin ${ }^{3}$ \\ ${ }^{1}$ Datatel-Ural, Ekaterinburg, Russia \\ ${ }^{2}$ Ural Federal University, Ekaterinburg, Russia; e-mail: sinitsyn_ev@mail.ru \\ ${ }^{3}$ Ministry of Transport of Sverdlovsk Region, Ekaterinburg, Russia
}

\begin{abstract}
This article describes a probabilistic mathematical model which can be used to analyse traffic flows in a road network. This model allows us to calculate the probability of distribution of vehicles in a regional road network or an urban street network. In the model, the movement of cars is treated as a Markov process. This makes it possible to formulate an equation determining the probability of finding cars at key points of the road network such as street intersections, parking lots or other places where cars concentrate. For a regional road network, we can use cities as such key points. This model enables us, for instance, to use the analogues of Kirchhoff First Law (Ohm's Law) for calculation of traffic flows. This calculation is based on the similarity of a real road network and resistance in an electrical circuit. The traffic flow is an analogue of the electric current, the resistance of the section between the control points is the time required to move from one key point to another, and the voltage is the difference in the number of cars at these points. In this case, well-known methods for calculating complex electrical circuits can be used to calculate traffic flows in a real road network. The proposed model was used to calculate the critical load for a road network and compare road networks in various regions of the Ural Federal District.
\end{abstract}

\section{KEYWORDS}

probabilistic mathematical model, traffic flows, Ohm's Law, Kirchhoff's First Law, regional road network, traffic management

\section{FOR CITATION}

Tolmachev, A. V., Sinitsyn, E. V., \& Brusyanin, D. A. (2019) Transport system modelling based on analogies between road networks and electrical circuits. R-economy, 5(2), 92-98. doi: 10.15826/recon.2019.5.2.010

\section{Моделирование транспортной системы на основе аналогий между дорожными сетями и электрическими цепями}

\author{
А. В. Толмачев ${ }^{1}$, Е. В. Синицын ${ }^{2} \bowtie$, Д. А. Брусянин ${ }^{3}$ \\ ${ }^{1}$ Датател-Урал, Екатеринбург, Россия \\ 2 Уральский федеральный университет, Екатеринбург, Россия; e-mail: sinitsyn_ev@mail.ru \\ ${ }^{3}$ Министерство транспорта и дорожного хозяйства Свердловской области, Екатеринбург, Россия
}

\section{АННОТАЦИЯ}

Предложена вероятностная математическая модель, позволяющая анализировать транспортные потоки в дорожной сети. Эта модель позволяет рассчитать вероятность распределения транспортных средств по дорожной сети региона или улично-дорожной сети города. В модели движение автомобилей трактуется как марковский процесс. Это позволяет сформулировать уравнение, определяющее вероятность нахождения автомобилей в ключевых точках дорожной сети. В качестве таких ключевых точек можно рассматривать, например: пересечение улиц в городах, парковки или другие места скопления автомобилей. В региональной сети автомобильных дорог в качестве таких ключевых точек можно рассматривать города. С помощью этой модели была показана, в частности, возможность использовать аналоги первого закона Кирхгофа (закона Ома) для расчета транспортных потоков. Этот расчет основан на эквивалентности реальной дорожной сети электрическим цепям сопротивлений. Транспортный поток является аналогом электрического тока, сопротивление участка между контрольными точками - это время, необходимое для перехода из одной ключевой точки в другую, напряжение - это разница в количестве автомобилей в этих точках. В этом случае для расчета транспортных потоков в реальной дорожной сети могут использоваться общеизвестные методы расчета сложных электрических цепей. Предложенная модель использовалась для расчета критической нагрузки в дорожной сети и сравнения дорожной сети в различных областях Уральского Федерального округа по этому показателю.

\section{КЛЮЧЕВЫЕ СЛОВА}

вероятностная математическая модель, транспортные потоки, закон Ома, первые аналоги закона Кирхгофа, региональные дорожные сети, управление транспортными потоками

\section{ДЛЯ ЦИТИРОВАНИЯ}

Tolmachev, A. V., Sinitsyn, E. V., \& Brusyanin, D. A. (2019) Transport system modelling based on analogies between road networks and electrical circuits. R-economy, 5(2), 92-98. doi: $10.15826 /$ recon.2019.5.2.010 


\section{Introduction}

The task of modelling road network dynamics is a widely discussed topic in modern research literature [1-6]. Despite the availability of fairly complex software systems, such as VISUM, it is still quite difficult to build simple models that would allow us to analyse the distribution of traffic flows across the road network, without detailed information about the social, age and gender structure of the population. Such macro-analysis is necessary, for example, in strategic planning for the development of urban transport, an integrated transport service system and in dealing with other problems.

In all these cases, it is useful to analyse not the traffic flows that occur in specific periods of time in a specific socio-economic, demographic and transport context, but objective characteristics of the transport network itself determined by its technical, geometric and topological factors. It is of theoretical and practical interest to compare such objective characteristics of transport networks of various cities with other macro-parameters characterizing their economic and social development.

In a number of works (see, for example [1]), the authors used models based on analogies between the transport flow and the flow of electric current through resistance circuits. Such an analogy is justified by the fact that the movement of automobiles, which is to some extent similar to the movement of electrons in a conductor, can be measured by the number of corresponding units passing through a certain section per unit of time, while the movement itself is caused by the external electromotive force. In this case we can use the analogue of Ohm's Law for the road section between points 1 and 2 (Figure 1): [7]

$$
I=\frac{U}{R}=\sigma U \text {. }
$$

Here $I$ is an analogue of electric current traffic flow, defined as the number of cars passing through the road cross-section per unit of time. $U$ is an analogue of voltage. It is natural to assume that the analogue of the electric field strength, the force causing the movement of electric charges, is the gradient of the number of cars going along the road in a certain direction. Thus, $U$ is the difference of the number of cars between points 1 and 2 .

The analogue of electric resistance for a highway section of the length - $L$ (one row) with the allowed speed of movement $v_{0}$ - looks the following way:

$$
R=\frac{L}{v_{0}}
$$

Respectively:

$$
\sigma=R^{-1}=\frac{v_{0}}{L} .
$$

The scheme for calculating "resistance" for a specific road section is shown in Figure 1. If we measure $I$ as the number of cars passing per unit of time through the cross section of the road part $1 \rightarrow 2$, for example: [I] = Number of cars per second, we can enter the current density $j$ : [8]

$$
\vec{j}=\frac{I}{h} \overrightarrow{d l}=\lambda \vec{E}=\frac{\vec{E}}{\rho},
$$

Here $h$ is the width (cross section), $\vec{E}$ is an analogue of the "electromotive force", $\overrightarrow{d l}$ is the vector along the elementary section of the road, $\rho$ and $\lambda$ are the "resistivity" and "conductivity" of the road section, respectively. Comparing (3a) with the traditional expression for $\vec{j}$ :

$$
\vec{j}=n \cdot \overrightarrow{v_{0}},
$$

where $n$ is the surface density of cars, we obtain the following:

$$
\begin{gathered}
E=n \cdot h, \\
\rho=h \cdot v_{0} .
\end{gathered}
$$

Dimensions of the values in (3) (we will assume that time is measured in seconds - [sec], length in meters - $[\mathrm{m}]$, number of cars in units [units]) are as follows:

$$
\begin{gathered}
{[I]=\frac{\text { unit }}{\sec },} \\
{[j]=\frac{u n i t}{\sec \cdot m},} \\
{[\rho]=\sec ,}
\end{gathered}
$$

From (3c) we get:

$$
[E]=\frac{\text { unit }}{m} .
$$

After taking an integral of both parts in (3a) along the road section between points 1 and 2, we find an analogue of Ohm's Law:

$$
U=\oint_{1}^{2} \vec{E} \cdot \overrightarrow{d l}=I \oint_{1}^{2} \frac{\rho}{h} d l=I \cdot R_{12}
$$




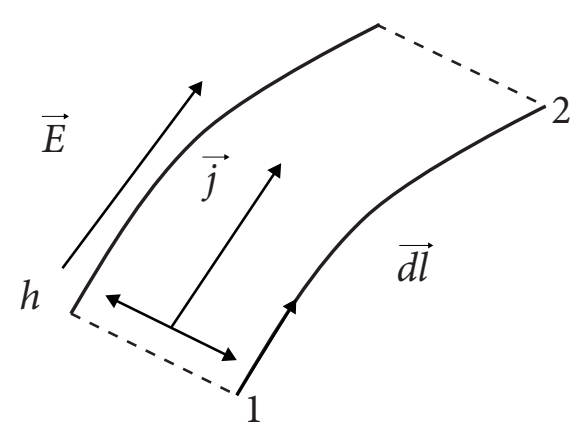

Figure 1. Scheme for calculating the "resistance" of the road section

$R_{12}$ in (5) is the "resistance" of the road section between points 1 and 2. For the permanent velocity along the road section from (5) one can easily obtain formulae (1), (2). The analogy between the traffic flow and electrical current in conductors is described in more detail in the next section ${ }^{1}$. We are going to use the above-described formulae to compare regional transport systems (see Section 3).

The analogy mentioned above can be used for various purposes. Firstly, it is convenient to make calculations regarding traffic flows in systems of arbitrary complexity by applying standard approaches such as the methods used for the calculation of electrical circuits [7]. For example, two parallel roads between points 1 and 2 (or two rows of traffic on the same road) can be compared to a parallel connection of electrical resistances. In full accordance with the formulas for calculating electrical circuits, the "resistance" of such a road is two times less, and the conductivity is twice as high as that of a road with single-row traffic. Surely, the calculation of traffic flows in real road networks, taking into account all the existing interconnections and conditions, is a rather complicated computational problem, but methods for solving such tasks are well developed [7]. Secondly, this analogy can be used to compare transport systems of different regions. In this case, the "resistance" (or "conductivity") of a regional road network can be used for such a comparison (for more on this see Section 3).

The laws describing the current flow in conductors can also be formulated so that the electric current will be the number of electrons flowing through a conductor cross section per unit of time (instead of its traditional definition the amount of charge flowing per unit of time through the conductor cross section). In this case, in the SGS system, the resistivity will be measured in seconds [sec], and $|\vec{E}|$, in units per meter [unit / m].

\section{Probabilistic mathematical model}

Let us now focus on the proposed mathematical model. This model also has an independent value. It allows us to calculate the probabilities of distribution of vehicles along a road network and to estimate the risks of traffic collapses. Let us consider an equation describing the probability that in a road network containing $n$ intersections ${ }^{2}$, at intersection 1, there are $X_{1}$ cars, at intersection $2, X_{2} \ldots$, at intersection $n, X_{n}$. We will describe the distribution of cars at intersections by the following vector:

$$
\vec{X}=\left\{X_{1}, X_{2}, \ldots, X_{n}\right\}=X,
$$

where

$$
\sum_{i=1}^{n} X_{i}=M
$$

where $M$ is the total number of the cars on the roads of the city. In this case, as it was shown in [9], the desired probability $P(\vec{X} \mid t)$ satisfies the equation:

$$
\begin{gathered}
\frac{\partial P(\vec{X} \mid t)}{\partial t}=P(\vec{X} \mid t)\left\{(1-z) \sum_{i=1}^{n} P_{i i}-\sum_{i=1}^{n} X_{i}\right\}+ \\
+z \sum_{i=1}^{n}\left(X_{i}+1\right) P\left(\ldots, X_{i+1}, \ldots \mid t\right)+ \\
\left.+(1-z) \sum_{i=1, j \neq i}^{n} P_{i j}\left(X_{i}+1\right) P\left(\ldots, X_{i+1}, \ldots, X_{j-1}, \ldots \mid t\right)\right\},
\end{gathered}
$$

$z$ is the probability of leaving the road, let $z=0$ for the sake of simplicity, $P_{i j}$ is the probability of moving a car from intersection $i$ to intersection $j$. It is obvious that

$$
\sum_{j=1}^{n} P_{i j}=1,
$$

Let us calculate the averages [10]:

$$
\overline{X_{i}}=<X_{i}>=\int_{0}^{M} X_{i} P(\vec{X} \mid t) d X_{i},
$$

and dispersion:

$$
\begin{gathered}
\sigma_{i j}=\overline{\left(X_{i}-<X_{i}>\right)\left(X_{j}-<X_{j}>\right)=} \\
\int_{0}^{M} X_{i} \cdot X_{i} \cdot P(\vec{X} \mid t) d X_{i} \cdot d X_{j}-<X_{i}>\cdot<X_{j}>.
\end{gathered}
$$

2 Each intersection is a key point of the road network such as a real intersections of city streets, parkings, and other places of cars concentration. For regional road networks we can use cities as such key points. 
It can be shown that

$$
\begin{aligned}
\overline{X_{i}} & \sim M, \\
\sigma_{i j} & \sim \sqrt{M} .
\end{aligned}
$$

Here $M$ is the total number of cars. Thus, as the coefficients of variation tend towards zero:

$$
C_{V}(i j) \sim \frac{1}{\sqrt{M}} \rightarrow 0
$$

Multiplying (4) by and carrying out some simple transformations, we get the following:

$$
\frac{\partial<X_{l}>}{\partial t}=\sum_{k=1}^{n}\left[\widetilde{P_{k l}} \cdot<X_{k}>-\widetilde{P_{l k}} \cdot<X_{l}>\right]
$$

here $\widetilde{P_{k l}}=0$ for $k=l ; \widetilde{P_{k l}}=P_{k l}$ for $k \neq l . P_{k l}$ are defined in comments to equation (4) $k \neq 1$.

It can be easily seen that for

$$
\frac{\partial<X_{l}>}{\partial t}=0
$$

(15) is equal to Kirchhoff's First Law for the electrical network [7]. Cars $<X_{l}>$ play the role of nodal potentials, and transition probabilities $\widetilde{P_{k l}}$ play the role of conductivities of sections of the road between intersections $k$ and $l$. It is easy to see that the dimensions of and correspond to formula (1) introduced in Section 1.

It is well known that (15) is also equal to the problem of random walks through the oriented graph whose vertices correspond to points $\left\{X_{1}, X_{2}, \ldots, X_{n}\right\}$ and the transition probabilities between the vertices are [11 12]. It should be mentioned that despite the fact that methods of graph theory are very popular in transportation modelling [13-15], it is interesting to consider the application of (15) for analysis of transport systems on the basis of the graph theory approach and methods of machine learning [16]. This question will be addressed in our following articles.

Despite the analogy drawn between road networks and electric circuits, it is still quite difficult to solve equation (15). One of the problems is how to determine the probabilities $P_{l k}$. In the simplest case, we can assume that they are determined solely by the network infrastructure and traffic management rules (a system of road signs, traffic signal change intervals, etc). With a more complex and rigorous approach, it is necessary to take into account the dependence of parameters on quantities, which will significantly complicate the task.

\section{Discussion}

First let us consider in more detail the effects that occur when a traffic flow passes through a section of a road of length $L$, for example, a part of a street between two intersections. Let us assume that for safe driving the distance between cars should not be less than the stopping distance in case of emergency braking $-l_{s}$. According to ${ }^{3}$ :

$$
l_{s}(v)=\frac{3 v}{10}+\left(\frac{v}{10}\right)^{2}
$$

where $v$ is the speed of the vehicle in $(\mathrm{km} / \mathrm{h})$. In this case, the density of the traffic flow should not exceed the value:

$$
j \leq \frac{v}{l_{s}(v)} \cdot \frac{1}{h} .
$$

With the help of (1) and (2) we can find that the value of "voltage" satisfies the condition:

$$
U_{c r} \leq \frac{L}{l_{s}(v)}=N_{c r},
$$

In (17), (18) $L$ is the length and $h$ is the width of the considered section of the road. It can be shown from (2), (3) and (5) that $U_{c r}$ is numerically equal to the total number of cars in this section of the road.

Let us now compare critical quantities $N_{c r}$ for different regions. We will use the data $^{4}$ on the total length of roads with a hard surface in the corresponding region and the fraction of the roads with improved surface. We will assume that on roads with improved surface, the speed is $90 \mathrm{~km} / \mathrm{h}$, and on roads with usual surface, 40 $\mathrm{km} / \mathrm{h}$. The exact value of these velocities is irrelevant for our comparison. These critical values $N_{c r}$ (18) will be compared with the current total number of cars in the region (public buses and private cars). Figure 2 shows the data for Sverdlovsk region in recent years. As it can be seen, the available number of cars significantly exceeds the critical one. This means that even a fraction

$$
f_{c r}=\frac{N_{c r}}{N},
$$

of the current number of cars on the region's roads will make normal movement impossible. The average value of fraction $f_{c r}$ for Sverdlovsk region is equal to $26 \%$.

It is interesting to compare $f_{c r}$ for different regions of the Ural Federal District. This compari-

\footnotetext{
${ }^{3}$ Retrieved from: http://www.1gai.ru

${ }^{4}$ Retrieved from: http://www.gks.ru
} 


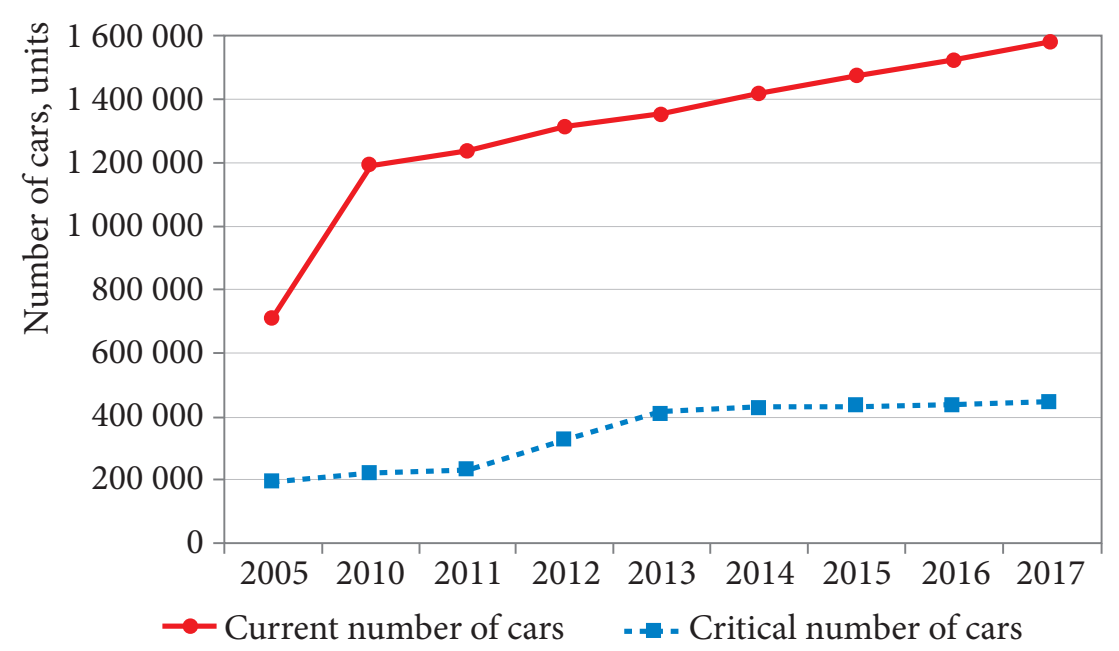

Figure 2. Dynamics of changes in the current and critical number of cars for Sverdlovsk region. The calculations were made by the authors on the basis of the official statistical data

(State Federal Statistics Service. Retrieved from: http://www.gks.ru/), by applying formulae (16)-(19)

son is illustrated by Figure 3. The results show that the transport systems of the regions in the Urals Federal District are under considerable pressure (with the exception, perhaps, of Kurgan region). For example, the massive use of private vehicles due to any reasons (holidays, emergencies etc.) in most regions is bound to lead to a traffic collapse.

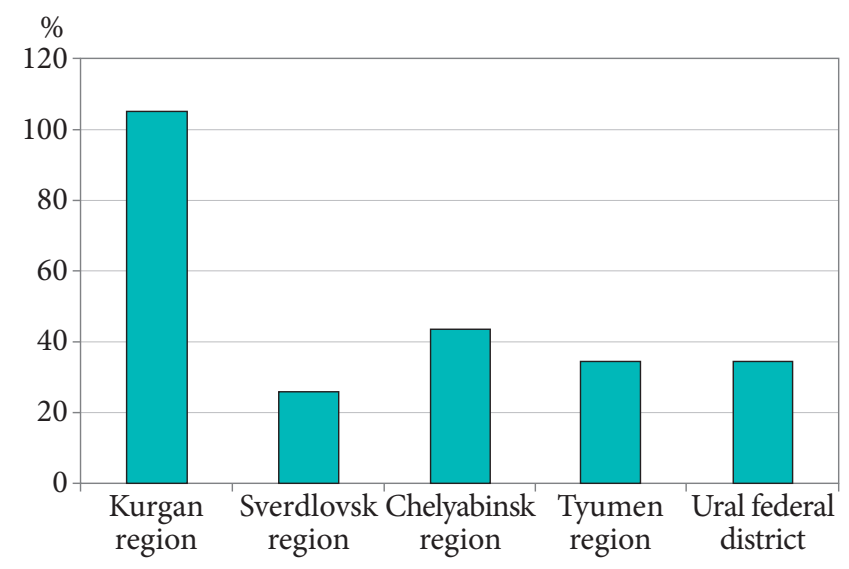

Figure 3. Fraction (19) for different regions. The authors made calculations by applying formula (19) and using the available statistical data (Regions of Russia. Key Characteristics of Subjects of the Russian Federation (2018). Moscow)

\section{Conclusion}

The above-described probabilistic mathematical model, which determines the distribution of cars along intersections of a road network, makes it possible to substantiate the analogy between the traffic flow and the electric current in an equivalent electric circuit where the resistances are the times needed for a car to travel along a certain road section.

At the same time, the main characteristics of effective electrical circuits that correspond to real road systems should be determined by taking into account the actual location of roads, their category, the number of traffic rows as well as the rules of traffic regulation.

In the cases when the road contains several rows, they can be considered as parallel resistances, the number of resistances corresponding to the number of rows. The described analogy makes it possible to reduce the task of calculating the traffic flow of the urban street-road network to the calculation of electric current in complex electrical circuits. Despite the fact that it is also a difficult task, it can be solved by using well-known methods and algorithms [17] implemented in various software applications.

In the future, we are planning to provide a detailed analysis of road networks in various regions, taking into account all the factors described above, as well as the social and economic characteristics of the regions (see below). However, in this article we limited ourselves to a comparative analysis of the critical capacity of the road network. The latter was understood as a critical number of cars that can simultaneously be on the roads of the region without violating traffic safety requirements.

Our analysis shows that in almost all of the given regions (Sverdlovsk, Chelyabinsk, and Tyumen regions) of the Ural Federal District, the 
number of the already existing personal vehicles and public buses significantly exceeds the critical throughput of the road network. The only exception is Kurgan region. It should be noted that cargo vehicles were not taken into account (partly, this was due to the lack of reliable data on the number of trucks on the roads of the Ural Federal District). Of course, if we took trucks into consideration, this picture would look even worse.

This situation indicates the potential instability of the work of road transport. Holidays, emergencies, bad weather conditions and so on may cause a significant increase in the use of motor vehicles or an increase in the "resistance" of road sections (for example, accidents, repair works) and cause traffic collapses.

In the future, we intend to present a more detailed system for comparison of regional transport systems by using the model described above. We are going to take into account the exact geographical location of the road network and traffic regulation rules; different types of transport; conditions of population settlements and their structure; and the location of economic objects and economic relations of territories.

We believe that this model can prove useful for strategic planning of transport systems and traffic management.

\section{References}

1. Antoniadi, G. D., \& Tsouprikov, A. A. (2015). Analysis of the problem areas in the Krasnodar transport network and activities to discharge them. Polythematic Online Scientific Journal of Kuban State Agrarian University, 8(112), 1-10.

2. Chowdhury, D., Santen, L., \& Schadschneider, A. (2000). Statistical physics of vehicular traffic and some related systems. Physics Reports, 329(4-6), 199-329.

3. Volkov, D. O., Garichev, S. N., Gorbachev, R. A., \& Moroz, N. N. (2015, November). Mathematical simulation of transport network load with a view to assessing viability of building new types of network systems. In: 2015 International Conference on Engineering and Telecommunication (EnT) (pp. 20-23). IEEE. (In Russ.)

4. Yakimov, M. R. (2013). Transport planning: creation of transport models of cities. Moscow: Logos. (In Russ.)

5. Crisostomi, E., Kirkland, S., \& Shorten, R. (2011). A Google-like model of road network dynamics and its application to regulation and control. International Journal of Control, 84(3), 633-651.

6. Melnikov, V. R., Krzhizhanovskaya, V. V., Boukhanovsky, A. V., \& Sloot, P. M. (2015). Data-driven modeling of transportation systems and traffic data analysis during a major power outage in the Netherlands. Procedia Computer Science, 66, 336-345. (In Russ.)

7. Bessonov, L. A. (1996). Theoretical Foundations of Electrical Engineering. Electrical circuits. Moscow: Higher School. (In Russ.)

8. Landau, L. D., \& Lifshits, E. M. (2005). Theoretical Physics, Vol. 8: Electrodynamics of Continuous Media. $4^{\text {th }}$ ed. Moscow: Fizmatlit. (In Russ.)

9. Astratova, G., Sinicin, E., Toporkova, E., Frishberg, L., \& Karabanova, I. (2017, June). Mechanism of information model development for company brand assessment within marketing strategy. In: International Conference on Trends of Technologies and Innovations in Economic and Social Studies 2017 (pp. 20-25). Atlantis Press. (In Russ.)

10. Amosova, N. N., Kuklin, B. A., \& Makarova, S. B. (2001) Probabilistic sections of mathematics. St. Petersburg. (In Russ.)

11. Leskovec, J., Rajaraman, A., \& Ullman, J. D. (2014). Mining of massive datasets. Cambridge University Press. ration.

12. Chartrand, G., \& Zhang, P. (2013). A first course in graph theory. New York: Courier Corpo-

13. Guze, S. (2014). Graph Theory Approach to Transportation Systems Design and Optimization. TransNav: International Journal on Marine Navigation and Safety of Sea Transportation, 8, 571-578.

14. Kumar Bisen, S. (2017). Application of Graph Theory in Transportation Networks. International Journal of Scientific research and Management, 5(7), 6197-6201. DOI: 10.18535/ijsrm/v5i7.48

15. Likaj, R., Shala, A., Mehmetaj, M., Hyseni, P., \& Bajrami, X. (2013). Application of graph theory to find optimal paths for the transportation problem. IFAC Proceedings Volumes, 46(8), 235-240. 
16. Géron, A. (2017). Hands-on machine learning with Scikit-Learn and TensorFlow: concepts, tools, and techniques to build intelligent systems. O'Reilly Media, Inc.

17. Mukhanov, V. V., \& Babenko A. G. (2009). Calculation of Complex Circuits. Yekaterinburg: GOU VPO USTU - UPI. (In Russ.)

\section{Authors}

Alexander V. Tolmachev - CEO, Datatel-Ural (12/8 Sibirsky trakt, 620100, Ekaterinburg, Russia); e-mail: at@idtu.ru

Evgeny V. Sinitsyn - Doctor of sciences, Professor, Ural Federal University (19 Mira St., 620002, Ekaterinburg, Russia); e-mail: sinitsyn_ev@mail.ru

Dmitrii A. Brusyanin - Deputy Minister of Transport of Sverdlovsk Region, Ministry of Transport of Sverdlovsk Region (1 Oktyabrskaya Square, 620014, Ekaterinburg, Russia); e-mail: dbrusyanin@mail.ru

ARTICLE INFO: received April 10, 2019; accepted June 3, 2019

\section{Информация об авторах}

Толмачев Александр Владимирович - генеральный директор Датател-Урал (620100, Россия, г. Екатеринбург, Сибирский тракт, 12/8); e-mail: at@idtu.ru

Синицын Евгений Валентинович - доктор физико-математических наук, профессор, ВШЭМ sinitsyn_ev@mail.ru (620002, Россия, г. Екатеринбург, ул. Мира, 19); e-mail: sinitsyn_ ev@mail.ru

Брусянин Дмитрий Алексеевич - заместитель министра транспорта и дорожного хозяйства Свердловской области (620014, Россия, г. Екатеринбург, пл. Октябрьская, 1); e-mail: dbrusyanin@mail.ru

ИНФОРМАЦИЯ О СТАТЬЕ: дата поступления 10 апреля 2019 г.; дата принятия к печати 3 июня 2019 г.

This work is licensed under a Creative Commons Attribution 4.0 International License

Эта работа лицензируется в соответствии с Creative Commons Attribution

4.0 International License 